\title{
Kepribadian Guru Dari Perspektif Siswa
}

\author{
Janantri Pasa ${ }^{1}$, Mahatma ${ }^{2}$ \\ ${ }^{12}$ Universitas Panca Sakti Bekasi \\ Email: janantri048@gmail.com, muhamad.mahatma@gmail.com
}

\begin{abstract}
The purpose of this study was to identify the teacher's personality competencies according to the students' perspective. This research was conducted in June-July 2021. The method used in this study was a descriptive method in the form of a survey. The survey was conducted through a google form in the form of a questionnaire (questionnaire). The research instrument consisted of five indicators and 15 questions. The results show that students most like teachers who have personalities who present themselves as steady, stable, mature, wise and authoritative. Overall, according to the student's perspective, the teacher's personality competence is good and can be an example and role model for students.
\end{abstract}

Keywords: Teachers Personality

Abstrak. Tujuan penelitian ini adalah untuk mengidentifikasi kompetensi kepribadian guru menurut perspektif para siswa. Penelitian ini dilaksanakan pada bulan Juni-Juli 2021. Metode yang digunakan dalam penelitian ini adalah metode deskriptif dalam bentuk survey. Survei dilakukan melalui google form berupa kuesioner (angket). Instrumen penelitian terdiri dari lima indikator dan 15 butir pertanyaan. Hasil menunjukkan bahwa siswa sangat menyukai guru yang memiliki pribadi yang menampilkan diri sebagai pribadi yang mantap, stabil, dewasa arif dan berwibawa. Secara keseluruhan, menurut perspektif siswa kompetensi kepribadian guru sudah baik dan bisa menjadi contoh dan suri tauladan bagi siswa.

Kata Kunci: Kepribadian Guru

\section{PENDAHULUAN}

Proses belajar mengajar merupakan inti dari proses pendidikan secara keseluruhan dengan guru sebagai pemegang peranan utama. Untuk itu, guru perlu memiliki standar profesi dengan menguasai materi serta strategi pembelajaran dan dapat mendorong siswanya untuk belajar bersungguh-sungguh. (Huda, 2018). Dalam dunia pendidikan peranan guru sangat penting, karena itulah guru dituntut untuk mempunyai kompetensi yaitu kemampuan atau kecakapan (Usman,1995:5). Kompetensi guru merupakan kemampuan seorang guru dalam melaksanakan kewajiban- kewajiban secara layak (Usman,1995:14).(Werdayanti dan Belakang, 2008)

Kompetensi guru adalah kemampuan yang ditampilkan oleh guru dalam melaksanakan kewajibannya memberikan pelayanan pendidikan kepada masyarakat.(Irwansyah, Diana Nsution dan Islam Negeri Sultan Syarif Kasim Riau, 2019)

Adapun kompetensi yang harus dimiliki oleh guru terdiri dari: 1. Kompetensi pedagogik yaitu kemampuan mengelola pembelajaran peserta didik yang meliputi pemahaman terhadap peserta didik, perancangan dan pelaksanaan pembelajaran, evaluasi hasil belajar, dan pengembangan peserta didik untuk mengaktualisasikan berbagai potensi yang dimilikinya. 2. Kompetensi kepribadian yaitu kepribadian pendidik yang mantap, stabil, dewasa, arif, dan berwibawa, menjadi teladan bagi peserta didik, dan berakhlak mulia. 3. Kompetensi sosial merupakan kemampuan pendidik berkomunikasi dan berinteraksi secara efektif dengan peserta didik, sesama pendidik, tenaga kependidikan, orang tua/wali peserta didik, dan masyarakat. 4. Kompetensi profesional adalah kemampuan pendidik dalam penguasaan materi pembelajaran secara luas dan mendalam yang memungkinkannya membimbing peserta didik memperoleh kompetensi yang ditetapkan. (Suhandani dan Kartawinata, 2014)

Dengan empat kompetensi tersebut diharapkan seorang guru mampu menjadi suri tauladan yang baik dalam segala hal bagi peserta didiknya. Guru juga membantu dalam membentuk watak peserta didik dengan cara memberikan keteladanan, cara berbicara atau 
menyampaikan materi dengan baik, terbuka dan toleransi.(Manan, 2018)

Mukhtar dan Iskandar (Depdiknas, 2001 : 31) mengemukakan bahwa pendidikan adalah usaha sadar yang dengan sengaja dirancangkan untuk mencapai tujuan yang telah ditetapkan. Pendidikan bertujuan untuk meningkatkan kualitas sumber daya manusia salah satu usaha untuk meningkatkan kualitas sumber daya manusia ialah melalui proses pembelajaran di sekolah. Proses kualitas manusia yang dibutuhkan oleh bangsa Indonesia pada masa yang akan datang adalah yang mampu menghadapi persaingan yang semakin ketat dengan bangsa lain di dunia. Kualitas manusia Indonesia tersebut dihasilkan melalui penyelenggaraan pendidikan yang bermutu. (Mulyani, 2015)

Kualitas manusia tentunya tidak terlepas dari kepribadian yang dimilikinya. Guru sering dianggap sebagai sosok yang memiliki kepribadian ideal. Karena itu, pribadi guru sering dianggap sebagai model atau panutan. Sanjaya (2011: 18) Guru harus mempunyai kompetensi yang berhubungan dengan pengembangan kepribadian (personal competencies), di antaranya; 1) kemampuan yang berhubungan dengan pengalaman ajaran agama sesuai dengan keyakinan agama yang dianutnya; 2) kemampuan untuk menghormati dan menghargai antar-umat beragama: 3) kemampuan untuk berperilaku sesuai dengan norma, aturan, dan sistem nilai yang berlaku di masyarakat; 4) mengembangkan sifat-sifat terpuji sebagai seorang guru, misalnya sopan santun dan tata krama: 5) bersifat demokratis dan terbuka terhadap pembaruan dan kritik. Kepribadian adalah faktor yang sangat berpengaruh terhadap keberhasilan seorang guru sebagai pengembang sunber daya manusia. Menurut Daradjat dalam Muhibbin (2010: 225): "Kepribadian itulah yang akan menentukan apakah ia menjadi pendidik dan pembina yang baik bagi anak didinya, ataukah akan menjadi perusak atau penghancur bagi hari depan anak didik terutama bagi anaka didik di tingkat sekolah dasar dan sekolah menengah".(Eka Aprilliyanti, Wahyu Wahyu, 2012)

Fakta tersebut menunjukkan bahwasanya kepribadian seorang guru masih menjadi permasalahan dalam pendidikan kita, sehingga perlu adanya pengkajian kembali tentang konsep kepribadian guru agar fungsi guru sebagai pendidik profesional dengan tugas utama mendidik, mengajar, membimbing, mengarahkan, melatih, menilai, dan mengevaluasi (Ahyudi, n.d.) bisa terealisasikan. (Pratama dan Musthofa, 2019)

Kompetensi kepribadian guru memiliki peran dan fungsi yang sangat penting dalam pengembangan karakter siswa. Mengesampingkan kompetensi kepribadian guru dapat berefek pada kenakalan siswa, cukup banyak siswa menyimpang dari norma agama dan negara, walaupun kasus kasus ini di luar proses pembelajaran, namun punya hubungan terhadap proses pembelajaran di sekolah.(Khaira et al., 2020)

Masalah kepribadian adalah suatu hal yang sangat menentukan tinggi rendahnya kewibawaan seorang guru dalam pandangan anak didik atau masyarakat (Djamarah, 2000). Kompetensi kepribadian guru merupakan kemampuan yang dimiliki seorang guru dalam bertindak dan berperilaku sebagai cerminan sikap yang layak sebagai seorang guru.(Yosi dan Kurniaman, 2020)

Keberadaan kompetensi kepribadian guru sangatlah penting. Menurut Uno (2018:58), Guru sebagai pendidik harus dapat memengaruhi siswa ke arah proses lebih baik sesuai dengan tata nilai yang dianggap baik dan berlaku dalam masyarakat.(Tugiono, 2020)

Pekerjaan sebagai guru adalah pekerjaan yang luhur dan mulia, baik ditinjau dari sudut masyarakat dan negara maupun ditinjau dari sudut keagamaan. Guru sebagai pendidik adalah seorang yang berjasa besar terhadap masyarakat dan negara. Tinggi atau rendahnya kebudayaan suatu masyarakat, maju atau mundurnya tingkat kebudayaan suatu masyarakat dan negara, sebagian besarnya tergantung kepada pendidikan dan pengajaran yang diberikan oleh 
guru-guru. Makin tinggi pendidikan guru, makin baik pula mutu pendidikan dan pengajaran yang diterima oleh anak-anak, dan makin tinggi pula derajat masyarakat.3 Oleh sebab itu, guru harus berkeyakinan dan bangga bahwa ia dapat menjalankan tugas itu. Guru hendaklah berusaha menjalankan tugas kewajiban sebaik-baiknya sehingga dengan demikian masyarakat menginsafi sungguh-sungguh betapa berat dan mulianya pekerjaan guru.(Oktradiksa, 2012)

Kepribadian guru mempengaruhi suasana proses belajar mengajar di kelas, kebebasan yang dinikmati peserta didik dalam mengeluarkan buah pikirannya dan mengembangkan kreativitasnya atau pengekangan dan keterbatasan yang dialaminya dalam pengembangan pribadinya. Guru sebagai pendidik dan pembangun generasi pembangun bangsa diharapkan dapat menunjukkan tingkah laku yang bermoral tinggi demi masa depan bangsa dan negara.(Suswanto, 2019)

Bagi seorang guru telah menjadi kewajiban baginya untuk menguasai materi yang menjadi tanggung jawabnya, serta mampu menerapkan metode-metode pembelajaran guna melaksanakan tugasnya yang menjadi tujuan pokok dalam sebuah pembelajaran. Penguasaan materi menjadi syarat mutlak karena gurulah yang menjadi sumber pokok pembelajaran di kelas. Proses transfer ilmu pengetahuan tidak akan dapat dilakukan apabila dari guru sendiri tidak menguasai materi yang diembannya.(Huda, 2018)

Indikator kompetensi kepribadian antara lain adalah rendah hati, pemaaf, jujur, ceria energik, selalu ingin maju, cermat, kreatif istiqamah, ulet, disiplin, adil, ikhlas, jujur, empati, berani, terbuka, gigih, pemurah, supel, sabar, humoris, humoris, penyayang, apresiatif, berwibawa, dan santun.(Lase, 2016)

Dari hasil pengamatan terhadap guruguru disekolah menunjukkan bahwa ada guru yang sangan memperhatikan perilaku siswanya. Mereka biasanya selalu meluangkan waktu untuk siswa di dalam dan di luar kelas. Ada guru yang hanya memperhatikan siswa selama pembelajaran berlangsung saja. Selain itu ada juga guru yang terkesan memperhatikan pencapaian target materi pembelajaran dibanding dengan perilaku siswanya.(Milfayetty, 2009)

Guru merupakan sosok yang begitu dihormati, guru sangat berperan dalam membantu perkembangan peserta didik, untuk menentukan tujuan hidupnya secara optimal. Ketika orang tua mendaftarkan ananknya kesekolah, pada saat itu juga ia menaruh harapan terhadap guru, agar anaknya berkembang secara optimal. Dengan demikian betapa pentingya peranan guru dalam proses belajar mengajar, disamping memberikan pengetahuan kepada siswa guru juga mempunyai tujuan untuk menjadikan saubjek didik mempunyai sikap dan tingkah laku yang sesuai dengan jiwa pancasila.(Rahmiyati, 2016)

Barinto (2012: 6) menjelaskan bahwa guru sebagai teladan bagi murid-muridnya yang harus memiliki sikap dan kepribadaian yang dapat dijadikan tokoh panutan idola dalam seluruh segi kehidupannya.(Dwintari, 2017)

Setiap guru memiliki kompetensi kepribadian yang berbeda-beda, namun menjadi seorang guru harus bisa membimbing, mengarahkan, dan juga memberikan motivasi terhadap setiap anak didiknya. Selanjutnya adalah bagaimana kompetensi kepribadian seorang guru yang baik kompeten menurut sudut pandang siswa? Apakah hanya guru-guru yang humoris atau memiliki jiwa kepemimpinan yang tinggi saja yang dimaksud dengan guru yang baik atau ada hal-hal lain yang disukai oleh para siswa mengenai karakter atau kepribadian guru, mengingat setiap anak didik memiliki pandangaan dan penilaian yang tidaklah sama. Penelitian ini akan membahas mengenai bagaimana kompetensi kepribadian guru dari perspektif siswa? kompetensi kepribadian guru yang seperti apa yang diinginkan oleh para siswa?

\section{METODE PENELITIAN}

Penelitian ini bersifat deskriptif dalam bentuk survey (Sugiyono, 2012) yaitu menggambarkan kompetensi kepribadian guru 
yang bagaimanakah yang baik menurut perspektif siswa. Penelitian ini di lakukan pada bulan juni sampai bulan juli tahun 2021, dan penelitian ini dilakukan di salah satu sekolah swasta yaitu Sekolah Menengah Pertama Walisongo Bekasi. Teknik dalam penelitian ini menggunakan kuisioner melalui google form. Dengan google form tersebut peneliti mengajukan pertanyaan kepada responden sebanyak 15 pertanyaan yang berkaitan dengan kompetensi kepribadian guru. Total populasi seluruhnya adalah 124 siswa dari jumlah tersebut terdapat 100 responden penelitian yang dilakukan. Instrumen penelitian terdiri dari 5 indikator dan 15 pertanyaan.

\section{HASIL PENELITIAN DAN PEMBAHASAN}

Dalam pembahasan ini peneliti akan membahas mengenai hasil data yang diperoleh. Data yang ada didapat dengan menggunakan menyebarkan kuesioner, dan setelah itu dilakukan direkapitulasi dan di analisa dengan bantuan aplikasi excel. Hasil rekapitulasi tersebut di analisa dengan menghitung rata-rata dari setiap indikator.

Tabel. 1 Analisis survei kepribadian guru

\begin{tabular}{|l|l|c|c|}
\hline No. & $\begin{array}{l}\text { Kompetensi Kepribadian } \\
\text { Guru }\end{array}$ & Skor & Ket. \\
\hline 1 & $\begin{array}{l}\text { Berperilaku sesuai dengan } \\
\text { hukum, agama, dan sikap } \\
\text { kebudayaan yang berlaku di } \\
\text { Indonesia. }\end{array}$ & 4,25 & Baik \\
\hline 2 & $\begin{array}{l}\text { Menampilkan diri sebagai } \\
\text { pribadi yang jujur, berakhlak } \\
\text { mulia dan teladan bagi peserta } \\
\text { didik dan masyarakat. }\end{array}$ & 4,453 & Baik \\
\hline 3 & $\begin{array}{l}\text { Menampilkan diri sebagai } \\
\text { pribadi yang mantap, stabil, } \\
\text { dewasa arif dan berwibawa. }\end{array}$ & 4,64 & Baik \\
\hline 4 & $\begin{array}{l}\text { Menunjukkan etos kerja, } \\
\text { anggung jawab yang tinggi, } \\
\text { rasa bangga menjadi guru dan } \\
\text { percaya diri. }\end{array}$ & 4,43 & Baik \\
\hline 5 & $\begin{array}{l}\text { Menjunjung tinggi kode etik } \\
\text { profesi guru. } \\
\text { Skor Kompetensi Kepribadian } \\
\text { Guru }\end{array}$ & 4,3706 & Baik \\
\hline
\end{tabular}

Dari tabel 1 dapat dilihat bahwa skor kompetensi kepribadian guru memperoleh nilai 4,3706, sehingga dapat dikatakan bahwa dari perspektif siswa, guru guru di SMP Wali Songo mempunyai kompetensi kepribadian yang baik.

Pada indikator pertama yaitu berperilaku sesuai dengan norma, hukum, sosial, dan kebudayaan nasional Indonesia dengan skor rata-rata sebesar 4,25 tergolong baik. Hal ini menunjukkan bahwa guru guru di SMP Walisongo mampu dengan baik menghargai peserta didik tanpa membedakan keyakinan yang di anut, suku, adat istiadat, daerah asal dan gender dan mampu dengan baik bersikap sesuai dengan norma agama yang dianut, hukum, norma sosial yang berlaku dalam masyarakat, serta kebudayaan nasional Indonesia yang beragam .

Pada indikator kedua yaitu guru mampu menampilkan diri sebagai pribadi yang jujur, berakhlak mulia dan teladan bagi peserta didik dan masyarakat memperoleh skor rata-rata sebesar 4,453 dengan keterangan baik. Hal ini menunjukkan bahwa guru guru di SMP Walisongo mempunyai kemampuan yang baik dalam hal : 1 . berperilaku jujur, tegas dan manusiawi. 2. berperilaku yang mencerminkan ketakwaan dan akhlak mulia. 3. berperilaku yang dapat diteladani oleh peserta didik dan anggota masyarakat di sekitarnya.

Pada indikator ketiga yaitu guru mampu menampilkan diri sebagai pribadi yang mantap, stabil, dewasa, arif dan berwibawa dengan skor rata-rata sebesar 4,64 yang bearti baik. Guru memiliki kepribadian yang mantap dan stabil, yaitu bertindak sesuai dengan norma sosial, bangga sebagai pendidik, dan memiliki konsistensi dalam bertindak sesuai dengan norma. Guru yang berkepribadian mantap dan stabil berarti tidak plinplan, terpercaya. Apa yang diucapkannya sesuai dengan tindakannya (Farisi 2011). Guru juga memiliki kepribadian yang dewasa, yaitu menampilkan kemandirian dalam bertindak sebagai pendidik dan memiliki etos kerja sebagai pendidik.(Syafe'i dan Maryani, 2020) 
Untuk menjadi guru seseorang harus memiliki kepribadian yang kuat dan terpuji. Kepribadian yang harus ada dalam pada diri guru yaitu kepribadian yang mantap, stabil, dewasa, arif dan berwibawa, menjadi teladan bagi peserta didik dan berakhlak mulia. Kepribadian yang mantap dan stabil memiliki indikator esensial, yaitu bertindak sesuai dengan norma hukum, bertindak sesuai dengan norma sosial, bangga sebagai guru dan memiliki konsistensi dalam bertindak dan berperilaku.(Rahmiyati, 2016)

Pada indikator keempat menunjukkan etos kerja, tanggung jawa yang tinggi, rasa bangga menjadi guru dan rasa percaya diri dengan skor rata-rata sebesar 4,43, yang bearti baik. Nilai skor tersebut menunjukkan bahwa guru guru di SMP Walisongo memiliki kemampuan yang baik dalam menunjukkan etos kerja dan tanggung jawab yang tinggi, bangga menjadi guru dan percaya pada diri sendiri dan mampu bekerja mandiri secara professional.

Yang terakhir adalah kemampuan menjunjung tinggi kode etik profesi guru dengan skor rata-rata sebesar 4,08 yang bearti baik. Guru memiliki citra diri positif sebagai pemilik profesi yang profesional dimata masyarakat, maka para guru telah mengembangkan kode etik guru profesional.(Fay, 1967). Profesionalisme guru diperlukan untuk memajukan pendidikan indonesia karena dengan mengingat berat dan kompleksnya membangun pendidikan, adalah sangat penting untuk melakukan upaya-upaya guna mendorong dan memberdayakan tenaga pendidik untuk semakin profesional. Hal ini tidak lain dimaksudkan untuk menjadikan upaya membangun pendidikan kokoh, serta mampu untuk terus menerus melakukan perbaikan ke arah yang lebih berkualitas. Profesi pendidik merupakan profesi yang sangat penting dalam kehidupan suatu bangsa. Hal ini tidak lain karena posisi pendidikan yang sangat penting dalam konteks kehidupan bangsa.(Mangkurat, 2021)

Guru yang menguasai kompetensi kepribadian akan sangat membantu upaya pengembangan karakter siswa. Dengan menampilkan sebagai sosok yang bisa digugu (didengar nasehatnya) dan ditiru (diikuti), secara psikologis anak cenderung merasa yakin dengan apa yang sedang diajarkan guru. Contohnya, ketika guru hendak mengajarkan tentang sopan santun kepada anak didiknya, namun disisi lain secara disadari ataupun seringkali tanpa disadari, gurunya sendiri malah cenderung bersikap kasar dan mudah marah, maka yang akan tertanam pada siswanya bukanlah sikap sopan santun, melainkan sikap kasar itulah yang lebih melekat pada sistem pikiran dan keyakinan siswanya.

Dari beberapa variabel di atas dapat dikatakan bahwa bapak ibu guru di SMP Walisongo Bekasi mempunyai kompetensi kepribadian yang baik sehingg dapat melaksanakan kewajibannya dengan penuh tanggung jawab dan memberikan contoh dab suri tauladan yang baik bagi peserta didik.

\section{KESIMPULAN}

Dari hasil penelitian di atas dapat di simpulkan bahwa kompetensi kepribadian guru yang harus diharapkan oleh siswa adalah guru yang memiliki kepribadian yang baik sesuai dengan norma agama, hukum, sosial, dan kebudayaan nasional Indonesia, jujur, berakhalak mulia, menjadi teladan, mantap, stabil, dewasa, arif dan bijaksana, berwibawa, memiliki etos kerja tinggi, tanggung jawab, rasa bangga menjadi guru, percaya diri, dan menjunjung tinggi kode etik guru.

\section{UCAPAN TERIMAKASIH}

Para peneliti mengucapkan terimakasih pada para guru, kepala sekolah dan semua pihak yang dapat membantu kegiatan penelitian ini sehingga dapat berjalan dengan baik.

\section{DAFTAR PUSTAKA}

Damayanti, T., Hamdan, S. R. dan Khasanah, A. N. (2017) "Kompetensi Guru Dalam

Proses Pembelajaran Inklusi Pada Guru SD Negeri Kota Bandung," Journal of Psychological Research, 3(1), hal. 7988.

Dwintari, J. W. (2017) “Kompetensi Kepribadian 
Jurnal Ilmiah Mandala Education

http://ejournal.mandalanursa.org/index.php/JIME/index

Terakreditasi Peringkat 4 (No. SK: 36/E/KPT/2019)

Guru dalam Pembelajaran Pendidikan

Kewarganegaraan Berbasis Penguatan

Pendidikan Karakter," Jurnal

Pendidikan Kewarganegaraan, 7, hal.

51-57. Tersedia pada:

https://ppjp.ulm.ac.id/journal/index.php

/pkn/article/view/4271.

Eka Aprilliyanti, Wahyu Wahyu, R. A. (2012)

"Hubungan Kompetensi Kepribadian Guru

Pkn Dengan Sikap Demokratis Peserta Didik Di Smk Negeri 1 Banjarmasin,"

Jurnal Pendidikan Kewarganegaraan, 3(10), hal. 354-364.

Fay, D. L. (1967) Angewandte Chemie International Edition, 6(11), 951-952.

Guru, K. et al. (2017) "Pengaruh Motivasi Kerja , Kompetensi Mengajar Dan Jakarta," 3(1), hal. 28-42.

Huda, M. (2018) "Kompetensi Kepribadian Guru Dan Motivasi Belajar Siswa (Studi

Korelasi Pada Mata Pelajaran Pai)," Jurnal Penelitian, 11(2), hal. 237-266. doi: 10.21043/jupe.v11i2.3170.

Irwansyah, M., Diana Nsution, M. dan Islam Negeri Sultan Syarif Kasim Riau, U. (2019)

"Urgensi Kompetensi Kepribadian Guru Dalam Sistem Pendidikan Perspektif Hadits Nabawi," Tarbiyah Islamiyah: Jurnal Ilmiah Pendidikan Agama Islam, $9(2)$.

Isrul (2017) "Pengaruh Kepribadian Guru Biologi Terhadap Motivasi Belajar Peserta Didik

Di Smp N 3 Mattirosompe," Jurnal Biology Science Dan Education, 6(2), hal. 138-147.

Khaira, W. et al. (2020) "KOMPETENSI KEPRIBADIAN GURU BERSERTIFIKAT

Pendahuluan Upaya pemerintah dalam mendongkrak kinerja guru adalah lewat program sertifikasi, baik dari segi pembelajaran maupun dari segi sertifikasi dalam jabatan, sehingga para guru lebih semangat dan energik," 10(3), hal. 387-401.

Kristoto, P. E. S., Zakso, A. dan Rivaie, H. W. (2015) "Pengaruh kompetensi kepribadian

guru terhadap keberhasilan siswa dalam belajar sosiologi sma kemala bhayangkari 1," Jurnal Pendidikan dan Pembelajaran Untan, vol. 4, no. 12, 29 Dec. 2015., 4(12).

Kurniadi, A., Popoi, I. dan Mahmud, M. (2020)
Vol. 7. No. 3 Agustus 2021

p-ISSN: 2442-9511 e-ISSN: 2656-5862

"Pengaruh Kompetensi Profesional Guru

Terhadap Motivasi Belajar Siswa,"

Jambura Economic Education Journal,

2(1). doi: 10.37479/jeej.v2i1.4425.

Lase, F. (2016) "Kompetensi Kepribadian Guru Profesional," Jurnal PPKn dan Hukum,

11(1), hal. 36-66. Tersedia pada: https://ejournal.unri.ac.id/index.php/JPB/art icle.

Ma nan, M. A. (2018) "Internalisasi Nilai-nilai Karakter dalam Meningkatkan Kompetensi

Kepribadian Guru di SMP Ibrahimy 1

Sukorejo Situbondo," Jurnal

Pendidikan Islam Indonesia, 3(1), hal.

18-31. doi: 10.35316/jpii.v3i1.84.

Mangkurat, U. L. (2021) “Meningkatkan Profesional profesi Guru Menuju Indonesia

Cerdas," 1(2), hal. 1-8.

Milfayetty, S. (2009) "Hubungan kompetensi kepribadian guru dan reinforcement dengan motivasi belajar di SMA negeri 11 Medan," Jurnal Alitika, hal. 1-11. Tersedia pada: http://www.ojs.uma.ac.id/index.php/ana litika/article/view/686/596.

Mulyani, F. (2015) "KONSEP KOMPETENSI GURU DALAM UNDANG-UNDANG

NOMOR 14 TAHUN 2005 TENTANG GURU DAN DOSEN ( Kajian Ilmu Pendidikan Islam )," Jurna Pendidikan Universitas Garut, 03(01), hal. 1-8.

Nuryovi, N., Wiharna, O. dan Sriyono, S. (2018) "Persepsi Siswa Tentang Kompetensi

Pedagogik dan Kompetensi Kepribadian Guru," Journal of Mechanical Engineering Education, 4(2), hal. 219. doi: 10.17509/jmee.v4i2.9636.

Oktradiksa, A. (2012) "Pengembangan Kualitas

Kepribadian Guru," Nadwa, 6(2), hal. 231. doi: 10.21580/nw.2012.6.2.590.

Pratama, A. I. dan Musthofa, M. (2019) "Konsep Kepribadian Guru Menurut Ibnu Sahnun,"

Tawazun: Jurnal Pendidikan Islam, 12(1), hal. 94. doi: 10.32832/tawazun.v12i1.1891.

Rahmiyati, Y. (2016) "Korelasi antara Kompetensi Kepribadian Guru dengan Minat dan

Aktifitas Belajar Siswa di Madrasah Aliyah Samarinda," SYAMIL: Jurnal Pendidikan Agama Islam (Journal of Islamic Education), 4(2), hal. 59-74. doi: 10.21093/sy.v4i2.713. 
Suhandani, D. dan Kartawinata, J. (2014) "Identifikasi Kompetensi Guru Sebagai Cerminan

Profesionalisme Tenaga Pendidik Di Kabupaten Sumedang (Kajian Pada Kompetensi Pedagogik)," Mimbar Sekolah Dasar, 1(2). doi: 10.17509/mimbar-sd.v1i2.874.

Suswanto (2019) "Kompetensi Kepribadian Guru (Suatu Konsep Teoritis dan Aplikasinya

Dalam Pembentukan Guru

Profesional)," Murabbi: Jurnal Ilmiah dalam Bidang Pendidikan, 02(01), hal. 65-78.

Syafe'i, I. dan Maryani, L. S. (2020) "Hubungan

Kompetensi Kepribadian Guru Bahasa

Arab Dengan Motivasi Belajar Siswa," Journal of Arabic Learning and Teaching, 9(2), hal. 147-155.

Tugiono, T. (2020) "Implementasi Kompetensi Kepribadian Kepala Sekolah dalam Meningkatkan Kompetensi Kepribadian Guru," Indonesian Journal of Education Management \& Administration Review, 4(1), hal. 215222.

Werdayanti, A. dan Belakang, L. (2008) "Pengaruh Kompetensi Guru Dalam Proses Belajar Mengajar Di Kelas Dan Fasilitas Guru Terhadap Motivasi Belajar Siswa," Dinamika Pendidikan, 3(1), hal. 79-92. doi: 10.15294/dp.v3i1.434.

Yosi, A. dan Kurniaman, O. (2020) "Analisis Kompetensi Kepribadian Guru Sekolah Dasar," 12(2), hal. 101-106.

Yulianti, WUlandari, D. A. (2019) "Seminar Nasional PGSD UNIKAMA

https://conference.unikama.ac.id/artikel / Vol. 3, November 2019," Pengaruh Model Bermain Peran Berbantuan Atribut Terhadap Hasil Belajar IPS Melalui Karakter Gotong Royong, 3(November), hal. 149-157. Tersedia pada:

https://conference.unikama.ac.id/artikel /index.php/pgsd/article/view/77. 